\title{
The Effect of Hydrolyzed Render Meal, Enzyme Treated Swine Skin Meal, and Cattle Skin Meal on Egg Production Performance, Eggshell Quality, Egg Quality, and Blood Characteristics in Laying Hens
}

\author{
M. M. Hossain ${ }^{1}$, J. H. Cho ${ }^{1}$ \& I. H. Kim ${ }^{1}$ \\ ${ }^{1}$ Department of Animal Resource and Science, Dankook University, Choongnam Cheonan, Korea \\ Correspondence: I. H. Kim, Department of Animal Resource and Science, Dankook University, Choongnam, \\ Cheonan, 330-714, Korea. Tel: 82-41-550-3652. E-mail: inhokim@dankook.ac.kr
}

Received: July 31, 2013 Accepted: May 27, 2014 Online Published: June 15, 2014

doi:10.5539/jas.v6n7p265 URL: http://dx.doi.org/10.5539/jas.v6n7p265

\begin{abstract}
The trial was conducted to investigate effect of hydrolyzed render meal and skin derived protein meal on the egg production performance, eggshell quality, egg quality and blood characteristics in laying hens. A total of 28044 week (wk) old (Hy-Line brown) laying hens were used in this 6- wk trial. Birds were randomly assigned to 1 of 4 treatments, 1) BD, basal diet; 2) HRM, basal diet with 2\% hydrolyzed render meal; 3) SSM, basal diet with 2\% swine skin meal; 4) CHM, basal diet with $2 \%$ cattle hide meal with 14 replications per treatment and 5 adjacent cages as replications. During wk- 44 to 46 , the egg production $(\%)$ was significantly higher $(\mathrm{P}<0.05)$ in SSM treatment $(96.37$ and 97.10) than others. Overall, egg production was higher $(\mathrm{P}<0.05)$ in SSM treatment (96.79\%) than CHM, HRM and BD treatments (96.16\%, 95.90\% and 95.30\%) respectively. In case of average daily feed intake $(\mathrm{ADFI}), \mathrm{SSM}$ showed significant higher $(\mathrm{P}<0.05)$ value $(120 \mathrm{~g})$ than BD treatment $(117 \mathrm{~g})$. Both SSM and CHM treatments seemed higher $(1.009)$ egg gravity than BD treatment $(\mathrm{p}<0.05)$ at 50- wk. On the other hand, at the same time, egg weight was significantly higher $(\mathrm{P}<0.05)$ in $\mathrm{BD}$ treatment compared to others. The egg quality and blood characteristics were unaffected $(\mathrm{p}>0.05)$ by dietary treatments. In a nut shell, the skin derived protein meal supplemented in laying hen diet at $2 \%$ enhanced the egg production performance of laying hens and inoffensive to the egg quality and laying hen health status.
\end{abstract}

Keywords: blood characteristics, cattle hide meal, egg gravity, hydrolyzed render meal, swine skin meal

\section{Introduction}

Nutritional ingredient plays the zenith role in feed formulation. Using unconventional feedstuff to the part of poultry diet is very effective and possible to make economic feed in the feed mill (Sahraei et al., 2012). The increased levels of meat and bone meal incorporated in poultry diets might reduce costs portionally as cheaper protein, calcium and phosphorus source than those conventional feedstuffs (Waldroup, 2002). The Dramatic changes in animal and poultry slaughter technologies have made it possible to produce a variety of animal and poultry offal such as meat and bone meal, poultry by-product meal, feather meal, blood meal and animal skin meal through the separate processing lines. Usually, fellmongery department handles skins and hides to produce pelts, pickled hides, wool, and hair but it has enormous potentiality to be used as a poultry feed. Processed animal proteins have been used by nutritionists in poultry for many years (Dale, 1997; Parsons et al., 1997; van Krimpen et al., 2010). The advantages of processed animal protein in poultry diets have been suggested as high digestibility of animal acids, as well as the bioavailability of amino acids (Sell \& Jeffrey, 1996; Parsons et al., 1997). Liberalization of the European Union regulations was announced regarding the use of processed animal protein in the diets of non-ruminant animals appropriate for human consumption (C3 material, pigs and poultry in 2005; The TSE (transmissible spongiform encephalopathies) Roadmap; European Commission, 2005).

The protein of meat by-products is of good quality (McDonald et al., 2002) but it was not always easy to incorporate to the animals (Simeonova \& Dalev, 1996; Zhao et al., 2009). Animal derived protein from render house such as meat meal and meat and bone meal are widely used in pig and poultry nutrition (Karakas et al., 2001). Researches (Leeson \& Zubair, 1994; McDonald et al., 2002) noted that meat meal was used successfully as the sole animal protein source in broilers and laying hens rations. Hydrolyzed render meal (HRM) is also a kind of protein from render house. Enzyme treated swine skin meal and cattle skin meal can be used as an 
alternative of high prized conventional feedstuffs in poultry diet without any harmful effects. The use of enzymatic digestion could improve the feeding value of by-product feeds has been reported by Woodgate (1994). As the level of unhydrolyzed leather meal was increased $(0,3,6$, or $9 \%)$ in poultry diets gain and feed intake was reduced (Pinheiro et al., 1989). In addition, Lindemann et al. (2000) noted that enzymatic treatment improved the quality of protein. However, enzymatic treated skin protein meal fed to layer was rarely reported.

Therefore, this study was conducted to evaluate hydrolyzed render meal (HRM), enzyme treated swine skin meal, and cattle skin meal on egg production performance, eggshell quality, egg quality, and blood characteristics in laying hens.

\section{Materials and Methods}

The animal care and use protocol was approved by the Animal Care and Use Committee of Dankook University.

\subsection{Supplementation of Animal Protein Sources}

The HRM and enzyme treated skin meal was obtained from Woosin food company (Pocheon, Gyeonggi, Korea). HRM produced by dry processing method under $130{ }^{\circ} \mathrm{C}$ and $500 \mathrm{kpa}$ of steam. Raw swine skin and cattle hide was washed with clean water for $10 \mathrm{~min}$. This washed raw skin was then soaked in $0.5 \% \mathrm{Na}_{2} \mathrm{~S}$ and $0.3 \%$ nonionic surfactant solution for $18 \mathrm{~h}$. Take out the skin and washed it for $20 \mathrm{~min}$ and then soaked it with $0.5 \%$ $\mathrm{Na}_{2} \mathrm{CO}_{3}$ for $18 \mathrm{~h}$. At last, the skin was washed and then were cut into smaller pieces and pulverized with mill. The powder was then soaked with 30 volumes of $0.5 \mathrm{M}$ acetic acid containing $1 \%$ pepsin $(1: 10000$, calculated on the dry weight of raw skin) at $4{ }^{\circ} \mathrm{C}$ for $48 \mathrm{~h}$. The mixture was centrifuged at $2000 \mathrm{~g}$ for $15 \mathrm{~min}$ and then the sediment and supernatant were dried separately. The powders were mixed to form the final product.

\subsection{Experiment and Design}

A total of 28044 -wk-old (Hy-Line brown) laying hens with initial body weight $1.92 \pm 1.77 \mathrm{~kg}$ were used in this 6-wk trial. Birds were randomly assigned to 1 of 4 treatments with 14 replications per treatment and 5 adjacent cages as a replication (hens were caged individually).The experimental treatments were: i) BD, basal diet; ii) HRM, basal diet with $2 \%$ hydrolyzed render meal; iii) SSM, basal diet with 2\% swine skin meal; iv) CHM, basal diet with $2 \%$ cattle hide meal. All the diets were formulated to meet or excess the NRC (1994) nutrition requirement (Table 1). Dietary calcium $(\mathrm{Ca})$, phosphorus $(\mathrm{P})$, and crude protein were analyzed according to the procedures described by the AOAC (2003). Dietary Ca was assayed by atomic absorption spectrophotometry after wet ash procedures and $\mathrm{P}$ was determined by colorimetry. Amino acids content were measured using an amino acid analyzer (Beckman 6300, Beckman Coulter, Inc., Fullerton, California, U.S.A.) after 24-h $6 \mathrm{~N}$-HCl hydrolysis at $110^{\circ} \mathrm{C}$ (AOAC, 2003). Energy was determined by using a Parr 6100 oxygen bomb calorimeter (Parr instrument Co., Moline, Illinois, U.S.A.). The amino acid profile of different protein sources is prescribed in Table 2. 
Table 1. Diet composition (as-fed basis) ${ }^{1}$

\begin{tabular}{lllll}
\hline Ingredients, \% & BD & HRM & SSM & CHM \\
\hline Corn & 22.00 & 23.27 & 23.25 & 22.75 \\
Soybean meal (CP 46\%) & 21.50 & 19.03 & 19.50 & 21.00 \\
Hydrolyzed leather meal ( CP 65\%) & - & 2.00 & - & - \\
Swine skin meal( CP 52\%) & - & - & 2.00 & - \\
Cattle hide meal( CP 48\%) & - & - & - & 2.00 \\
Wheat & 31.90 & 30.90 & 29.90 & 30.60 \\
Grass meal & 2.00 & 2.15 & 2.75 & 1.00 \\
Rapeseed cake & 4.00 & 4.00 & 4.00 & 4.00 \\
Cornstarch & 6.00 & 6.00 & 6.00 & 6.00 \\
Rapeseed oil & 2.50 & 2.50 & 2.50 & 2.50 \\
Limestone & 7.50 & 7.50 & 7.50 & 7.50 \\
Tricalcium phosphate (P 18\%) & 1.70 & 1.70 & 1.70 & 1.70 \\
Salt & 0.30 & 0.30 & 0.30 & 0.30 \\
Lysine. HCl (78\%) & - & 0.05 & - & 0.05 \\
DL-Methionine(50\%) & 0.10 & 0.10 & 0.10 & 0.10 \\
Vitamin-mineral premix ${ }^{2}$ & 0.50 & 0.50 & 0.50 & 0.50 \\
\hline
\end{tabular}

Calculated composition, \%

\begin{tabular}{|c|c|c|c|c|}
\hline $\mathrm{ME}, \mathrm{kcal} / \mathrm{kg}$ & 2,739 & 2,788 & 2,740 & 2,789 \\
\hline $\mathrm{CP}$ & 16.80 & 16.75 & 16.80 & 16.80 \\
\hline $\mathrm{EE}$ & 5.78 & 6.29 & 6.97 & 6.88 \\
\hline Lys & 0.81 & 0.81 & 0.81 & 0.82 \\
\hline Met & 0.36 & 0.36 & 0.36 & 0.36 \\
\hline Met + Cys & 0.66 & 0.66 & 0.66 & 0.66 \\
\hline $\mathrm{Ca}$ & 4.37 & 4.37 & 4.37 & 4.37 \\
\hline Total P & 0.61 & 0.61 & 0.61 & 0.61 \\
\hline Available P & 0.37 & 0.37 & 0.37 & 0.37 \\
\hline \multicolumn{5}{|c|}{ Analyzed composition, \% } \\
\hline $\mathrm{ME}, \mathrm{kcal} / \mathrm{kg}$ & 2,725 & 2,730 & 2,728 & 2,729 \\
\hline $\mathrm{CP}$ & 16.78 & 16.80 & 16.81 & 16.80 \\
\hline Lys & 0.80 & 0.80 & 0.80 & 0.80 \\
\hline Met & 0.34 & 0.35 & 0.35 & 0.35 \\
\hline Met + Cys & 0.63 & 0.63 & 0.64 & 0.63 \\
\hline $\mathrm{Ca}$ & 4.35 & 4.35 & 4.36 & 4.35 \\
\hline Total P & 0.60 & 0.61 & 0.62 & 0.61 \\
\hline Available P & 0.35 & 0.36 & 0.37 & 0.36 \\
\hline
\end{tabular}

${ }^{1} \mathrm{BD}$, basal diet; HRM, hydrolyzed render meal; SSM, swine skin meal; CHM, cattle hide meal.

${ }^{2}$ The premix provided per $1 \mathrm{~kg}$ of diet: vitamin A, 10,000 IU; vitamin $\mathrm{D}_{3}, 3,000 \mathrm{IU}$; vitamin $\mathrm{E}, 50 \mathrm{IU}$; vitamin $\mathrm{K}_{3}, 2 \mathrm{mg}$; vitamin $\mathrm{B}_{1}, 1 \mathrm{mg}$; vitamin $\mathrm{B}_{2}, 4 \mathrm{mg}$; vitamin $\mathrm{B}_{6}, 1.5 \mathrm{mg}$; vitamin $\mathrm{B}_{12}, 0.01 \mathrm{mg}$; Capantothenate, $8 \mathrm{mg}$; niacin, $25 \mathrm{mg}$; folic acid, $0.5 \mathrm{mg}$; choline chloride, $250 \mathrm{mg}$; manganese, $100 \mathrm{mg}$; zinc, $50 \mathrm{mg}$; iron, $50 \mathrm{mg}$; copper, $8 \mathrm{mg}$; iodine, $0.8 \mathrm{mg}$; selenium, $0.2 \mathrm{mg}$; cobalt, $0.2 \mathrm{mg}$. 
Table 2. Amino acids of different sources of protein meals ${ }^{1}$

\begin{tabular}{|c|c|c|c|c|}
\hline Amino acids, $\%$ & SBM & HRM & SSM & $\mathrm{CHM}$ \\
\hline Crude protein & 46.00 & 65.00 & 52.00 & 48.00 \\
\hline \multicolumn{5}{|c|}{ Essential amino acid $^{2}$} \\
\hline Arginine & 3.11 & 3.38 & 3.45 & 3.00 \\
\hline Histidine & 1.08 & 1.46 & 1.66 & 0.98 \\
\hline Isoleucine & 1.95 & 1.31 & 1.43 & 1.12 \\
\hline Leucine & 3.24 & 2.99 & 3.38 & 2.37 \\
\hline Lysine & 2.46 & 2.01 & 2.03 & 1.95 \\
\hline Methionine & 0.54 & 0.58 & 0.53 & 0.40 \\
\hline Phenylalanine & 2.15 & 1.83 & 2.17 & 1.30 \\
\hline Threonine & 1.68 & 0.98 & 0.95 & 1.34 \\
\hline Tryptophan & 0.45 & - & - & - \\
\hline Valine & 2.16 & 1.95 & 2.39 & 1.45 \\
\hline \multicolumn{5}{|c|}{ Non essential amino acid $^{2}$} \\
\hline Alanine & 1.95 & 4.47 & 5.46 & 3.52 \\
\hline Aspartic acid & 5.09 & 3.46 & 3.69 & 3.19 \\
\hline Cystine & 0.63 & 0.12 & 0.07 & 0.17 \\
\hline Glumatic acid & 8.22 & 6.75 & 7.11 & 5.20 \\
\hline Glycine & 1.89 & 8.35 & 10.69 & 6.73 \\
\hline Proline & 2.85 & 5.82 & 6.10 & 4.30 \\
\hline Serine & 2.24 & 1.34 & 0.90 & 1.89 \\
\hline Tyrosine & 1.67 & 1.27 & 1.46 & 0.81 \\
\hline
\end{tabular}

${ }^{1}$ SBM, soybean meal; HRM, hydrolyzed render meal; SSM, swine skin meal; CHM, cattle hide meal.

${ }^{2}$ Analyzed value.

\subsection{Housing}

Laying hens were raised in an ambient regulated house, in which temperature was maintained at $21{ }^{\circ} \mathrm{C}$ and light regime was set at $16 \mathrm{~h}$ light: $8 \mathrm{~h}$ darkness. Laying hens were individually reared in adjacent steel cages which equipped with nipple drinker, trough and egg collecting plate. Birds were fed ad libitum accessed to water and feed.

\subsection{Measurement of Parameters}

\subsubsection{Egg Production Performance}

Daily records of egg production and feed intake were kept throughout the experimental period. Egg production was expressed as an average production of hen per day, which was calculated from the total number of eggs divided by the number of experimental time (day as a unit) and summarized on an average basis. The average daily feed intake was calculated during whole period of trial weekly.

\subsubsection{Egg Shell and Quality}

A total of 28 saleable eggs (no shell defects, cracks, or double yolks) were randomly collected at 17:00 pm from each treatment ( 2 per replicate, $\mathrm{n}=28$ ) on a weekly basis and used to determine the egg shell and quality at 20:00 pm the same day. Egg weight was measured using an egg multi tester (Touhoku Rhythm Co. Ltd., Tokyo, Japan). The total average egg weight was calculated based on biweekly egg weight measurement. Eggshell color was determined using a color fan. Eggshell breaking strength was evaluated using a model II egg shell force gauge (Robotmation Co., Ltd., Tokyo, Japan). A dial pipe gauge (Ozaki MFG Co., Ltd., Tokyo, Japan) was used 
to measure egg shell thickness, which was determined based on the average thickness of the rounded end, pointed end, and the middle of the egg, excluding the inner membrane. Finally, egg yolk color, and Haugh Unit (HU) were evaluated using an egg multi-tester (Touhoku Rhythm Co. Lt., Tokyo, Japan). These eggs were immersed in a series of sodium chloride solution (0.010-increments between 1.060 and 1.110) to determine specific gravity (Yan et al., 2011).

\subsubsection{Blood Profile}

Blood samples were collected from the same laying hens by puncturing the wing vein using a sterilized syringe with needle (14 birds per treatment) at $0,2,4$, and 6 weeks of the experiment. For serum analysis, the blood samples were centrifuged at $2000 \mathrm{~g}$ at $4{ }^{\circ} \mathrm{C}$ for $20 \mathrm{~min}$ to separate the serum. The total protein in the serum was then analyzed using an automatic biochemistry blood analyzer (HITACHI747, Tokoyo, Japan). Whole blood samples from the $\mathrm{K}_{3}$ EDTA vacuum tube were analyzed to determine the haematocrit white blood cell (WBC), red blood cell (RBC), and lymphocyte concentrations using an automatic blood analyzer (ADVIA120, Bayer, Tarrytown, NY, USA). The same method was also carried out by Yan et al. (2011).

\subsection{Data Analysis}

All data were arranged to evaluate by analysis of variance following the general linear method (GLM) procedure in a completely randomized design using the SAS software program (SAS Institute, 1996). Laying hens were blocked with identical age. The statistical model included the main and interactive effects of age (weeks) and treatment. The difference among treatment was compared using the Duncan's multiple range test (Duncan, 1955). The treatment effect was observed significant with the probability value below 0.05 .

\section{Results}

\subsection{On Egg Production Achievement}

The egg production performance was shown in Table 3. The egg production was found highest in SSM treatment $(96.37 \%$ and $97.10 \%)$ and lowest $(\mathrm{P}<0.05)$ in BD $(95.39 \%$ and $95.40 \%)$ and HRM $(95.41 \%$ and $95.40 \%)$ treatments during 44 to 46 week. The egg production was higher $(\mathrm{P}<0.05)$ in HRM and SSM treatments than $\mathrm{BD}$ treatment at 48 week. At the 50 -wk age, the egg production was significantly higher $(\mathrm{P}<0.05)$ in HRM, SSM, and CHM treatments $(97.10 \%, 96.45 \%$ and $96.30 \%)$ compared with BD treatment $(95.20 \%)$. In the whole experimental period, egg production (\%) and ADFI (g) were proved significantly higher in SSM treatment than others $(\mathrm{P}<0.05)$.

Table 3. Effects of hydrolyzed render meal and animal skin meal on egg production performance in laying hens ${ }^{1}$

\begin{tabular}{|c|c|c|c|c|c|c|c|c|c|}
\hline \multirow{2}{*}{ Item, Trt } & \multirow{2}{*}{ wk } & \multirow{2}{*}{$\mathrm{BD}$} & \multirow{2}{*}{ HRM } & \multirow{2}{*}{ SSM } & \multirow{2}{*}{$\mathrm{CHM}$} & \multirow{2}{*}{$\mathrm{SE}^{2}$} & \multicolumn{3}{|c|}{ Main effects ${ }^{3}$} \\
\hline & & & & & & & wk & Trt & $\mathrm{wk} \times \mathrm{Trt}$ \\
\hline \multirow{4}{*}{ Egg production, \% } & 44 & $95.39^{c}$ & $95.41^{\mathrm{c}}$ & $96.37^{\mathrm{a}}$ & $96.02^{b}$ & 0.25 & NS & 0.03 & NS \\
\hline & 46 & $95.40^{\mathrm{c}}$ & $95.40^{\mathrm{c}}$ & $97.10^{\mathrm{a}}$ & $96.20^{\mathrm{b}}$ & 0.36 & NS & 0.03 & NS \\
\hline & 48 & $95.20^{\mathrm{b}}$ & $96.40^{\mathrm{a}}$ & $96.60^{\mathrm{a}}$ & $96.10^{\mathrm{ab}}$ & 0.31 & NS & 0.03 & NS \\
\hline & 50 & $95.20^{\mathrm{b}}$ & $96.40^{\mathrm{a}}$ & $97.10^{\mathrm{a}}$ & $96.30^{\mathrm{a}}$ & 0.21 & NS & 0.03 & NS \\
\hline \multicolumn{10}{|c|}{ Overall } \\
\hline Egg production, $\%$ & & $95.29^{\mathrm{c}}$ & $95.90^{\mathrm{b}}$ & $96.79^{\mathrm{a}}$ & $96.16^{\mathrm{ab}}$ & 0.23 & NS & 0.03 & NS \\
\hline ADFI, $g$ & & $117^{\mathrm{b}}$ & $118^{\mathrm{ab}}$ & $120^{\mathrm{a}}$ & $119^{\mathrm{ab}}$ & 1.1 & NS & 0.04 & NS \\
\hline
\end{tabular}

${ }^{1} \mathrm{BD}$, basal diet; HRM, basal diet with $2 \%$ hydrolyzed render meal; SSM, swine skin meal; CHM, cattle hide meal; Trt, treatmeant; wk, week.

${ }^{2}$ Standard error.

${ }^{3} \mathrm{NS}$, non-significant. $\mathrm{P}<0.05$ means significant effect.

${ }^{\mathrm{a}, \mathrm{b}}$ Means the same column with different superscripts differ $(\mathrm{P}<0.05)$.

\subsection{On Egg Shell Parameters}

No difference was observed in eggshell color, egg strength, and eggshell thickness biweekly or the overall period $(\mathrm{P}>0.05)$. The egg gravity was higher $(\mathrm{P}<0.05)$ in SSM and CHM treatments than those in BD treatments at 50 
week. The egg weight in BD treatment was greater than in other treatments at 50- wk. The egg weight was decreased $(\mathrm{P}<0.05)$ in skin derived protein supplemented treatments as the feeding time increased (Table 4$)$.

Table 4. Effects of hydrolyzed render meal and animal skin meal on eggshell parameters in laying hens ${ }^{1}$

\begin{tabular}{|c|c|c|c|c|c|c|}
\hline Item, wk & Trt & $\begin{array}{l}\text { Eggshell } \\
\text { color }\end{array}$ & $\begin{array}{l}\text { Egg weight, } \\
\mathrm{g}\end{array}$ & Egg gravity & $\begin{array}{l}\text { Eggshell } \\
\text { strength, } \mathrm{kg} / \mathrm{cm}^{2}\end{array}$ & $\begin{array}{l}\text { Eggshell thickness, } \\
0.01 \mathrm{~mm}\end{array}$ \\
\hline \multirow{4}{*}{44} & $\mathrm{BD}$ & 11.9 & 65.3 & 1.093 & 3.840 & 40 \\
\hline & HRM & 11.5 & 64.9 & 1.091 & 3.809 & 39 \\
\hline & SSM & 11.6 & 65.2 & 1.092 & 3.794 & 40 \\
\hline & CHM & 11.5 & 65.1 & 1.090 & 3.795 & 39 \\
\hline \multirow{4}{*}{46} & $\mathrm{BD}$ & 12.0 & 65.5 & 1.093 & 3.828 & 40 \\
\hline & HRM & 12.1 & 65.3 & 1.096 & 3.869 & 40 \\
\hline & SSM & 12.2 & 65.4 & 1.093 & 3.812 & 41 \\
\hline & CHM & 12.2 & 66.0 & 1.092 & 3.872 & 40 \\
\hline \multirow{3}{*}{48} & $\mathrm{BD}$ & 11.8 & 64.7 & 1.096 & 3.778 & 41 \\
\hline & HRM & 11.4 & 64.0 & 1.097 & 3.740 & 40 \\
\hline & SSM & 11.3 & 63.7 & 1.097 & 3.758 & 40 \\
\hline \multirow{6}{*}{50} & CHM & 11.3 & 63.7 & 1.094 & 3.725 & 40 \\
\hline & $\mathrm{BD}$ & 11.5 & $64.3^{\mathrm{a}}$ & $1.096^{\mathrm{b}}$ & 3.343 & 40 \\
\hline & HRM & 11.2 & $61.9^{\mathrm{b}}$ & $1.098^{\mathrm{ab}}$ & 3.213 & 40 \\
\hline & SSM & 11.4 & $62.9^{\mathrm{b}}$ & $1.099^{\mathrm{a}}$ & 3.415 & 40 \\
\hline & CHM & 11.0 & $61.3^{\mathrm{b}}$ & $1.099^{\mathrm{a}}$ & 3.533 & 40 \\
\hline & $\mathrm{BD}$ & 11.8 & 65.0 & 1.095 & 3.697 & 40 \\
\hline \multirow{3}{*}{ Overall period ${ }^{2}$} & HRM & 11.6 & 64.0 & 1.096 & 3.658 & 40 \\
\hline & SSM & 11.6 & 64.3 & 1.095 & 3.694 & 40 \\
\hline & CHM & 11.5 & 64.0 & 1.094 & 3.731 & 40 \\
\hline $\mathrm{SE}^{3}$ & & 0.33 & 0.63 & 0.002 & 0.178 & 0.48 \\
\hline \multicolumn{7}{|l|}{ Main effects ${ }^{4}$} \\
\hline wk & & NS & 0.02 & 0.03 & NS & NS \\
\hline Trt & & NS & NS & NS & NS & NS \\
\hline $\mathrm{wk} \times \operatorname{Trt}$ & & NS & NS & NS & NS & NS \\
\hline
\end{tabular}

${ }^{1} \mathrm{BD}$, basal diet; HRM, basal diet with $2 \%$ hydrolyzed render meal; SSM, swine skin meal; CHM, cattle hide meal; Trt, treatmeant; wk, week.

${ }^{2}$ The mean value of overall period data (44 wk to $50 \mathrm{wk}$ ).

${ }^{3}$ Standard error.

${ }^{4} \mathrm{NS}$, non-significant. $\mathrm{P}<0.05$ means significant effect.

${ }^{a, b}$ Means the same colum with different superscripts $\operatorname{differ}(\mathrm{P}<0.05)$.

\subsection{On Egg Quality}

The egg quality influenced by the dietary novel protein was shown in Table 5. The egg yolk color, yolk height, and Haugh Unit were unaffected $(\mathrm{P}>0.05)$ by dietary treatments. 
Table 5. Effects of hydrolyzed render meal and animal skin mealon egg quality in laying hens

\begin{tabular}{|c|c|c|c|c|}
\hline Item, wk & Trt & Yolk color & Yolk height, mm & Haugh Unit \\
\hline \multirow{3}{*}{44} & $\mathrm{BD}$ & 8.2 & 8.4 & 90.5 \\
\hline & HRM & 8.0 & 8.5 & 90.7 \\
\hline & SSM & 8.2 & 8.5 & 90.6 \\
\hline \multirow{6}{*}{46} & CHM & 8.1 & 8.3 & 90.3 \\
\hline & $\mathrm{BD}$ & 8.8 & 8.2 & 89.7 \\
\hline & HRM & 8.8 & 8.3 & 90.7 \\
\hline & SSM & 8.8 & 8.4 & 90.9 \\
\hline & CHM & 8.6 & 8.3 & 89.3 \\
\hline & $\mathrm{BD}$ & 8.5 & 8.6 & 91.3 \\
\hline \multirow{2}{*}{48} & HRM & 8.6 & 8.7 & 92.0 \\
\hline & SSM & 8.6 & 8.6 & 91.1 \\
\hline \multirow{6}{*}{50} & CHM & 8.4 & 8.6 & 91.4 \\
\hline & $\mathrm{BD}$ & 8.7 & 8.5 & 91.9 \\
\hline & HRM & 8.6 & 8.7 & 92.8 \\
\hline & SSM & 8.7 & 8.6 & 92.0 \\
\hline & CHM & 8.4 & 8.5 & 91.7 \\
\hline & $\mathrm{BD}$ & 8.6 & 8.4 & 90.9 \\
\hline Overall & HRM & 8.5 & 8.6 & 91.6 \\
\hline \multirow[t]{2}{*}{ Period } & SSM & 8.6 & 8.5 & 91.2 \\
\hline & CHM & 8.4 & 8.4 & 90.7 \\
\hline SE & & 0.13 & 0.13 & 0.83 \\
\hline \multicolumn{5}{|c|}{ Main effects ${ }^{1}$} \\
\hline wk & & NS & NS & NS \\
\hline Trt & & NS & NS & NS \\
\hline $\mathrm{wk} \times \mathrm{Trt}$ & & NS & NS & NS \\
\hline
\end{tabular}

${ }^{1} \mathrm{NS}$, non-significant.

\subsection{On Blood Parameters}

The blood characteristics were shown in Table 6. No difference was found in serum total protein, RBC, and WBC concentrations and lymphocyte level among dietary treatments. 
Table 6. Effects of hydrolyzed render meal and animal skin meal on blood profiles in laying hens

\begin{tabular}{|c|c|c|c|c|c|}
\hline Item & Trt & $\begin{array}{l}\text { Total protein } \\
\mathrm{g} / \mathrm{L}\end{array}$ & $\begin{array}{l}\mathrm{RBC} \\
10^{6} / \mathrm{mm}^{3}\end{array}$ & $\begin{array}{l}\text { WBC } \\
10^{3} / \mathrm{mm}^{3}\end{array}$ & $\begin{array}{l}\text { Lymphocyte } \\
\%\end{array}$ \\
\hline \multirow{4}{*}{44 week } & $\mathrm{BD}$ & 5.18 & 2.10 & 363.1 & 76.6 \\
\hline & HRM & 5.10 & 2.06 & 351.9 & 76.2 \\
\hline & SSM & 5.02 & 2.02 & 355.2 & 78.6 \\
\hline & $\mathrm{CHM}$ & 4.96 & 2.10 & 363.5 & 76.4 \\
\hline \multirow{4}{*}{46 week } & $\mathrm{BD}$ & 5.74 & 2.08 & 329.6 & 74.0 \\
\hline & HRM & 5.84 & 1.96 & 336.7 & 77.8 \\
\hline & SSM & 5.84 & 2.00 & 331.9 & 77.0 \\
\hline & CHM & 5.64 & 1.96 & 333.9 & 77.2 \\
\hline \multirow{4}{*}{48 week } & $\mathrm{BD}$ & 5.00 & 1.84 & 252.7 & 69.4 \\
\hline & HRM & 5.14 & 1.88 & 250.7 & 74.0 \\
\hline & SSM & 5.24 & 1.82 & 256.5 & 74.8 \\
\hline & $\mathrm{CHM}$ & 5.28 & 1.90 & 253.4 & 72.4 \\
\hline \multirow{4}{*}{50 week } & $\mathrm{BD}$ & 5.22 & 1.80 & 328.2 & 76.2 \\
\hline & HRM & 5.10 & 1.78 & 321.6 & 79.6 \\
\hline & SSM & 5.02 & 1.76 & 330.1 & 77.0 \\
\hline & $\mathrm{CHM}$ & 5.08 & 1.86 & 332.7 & 79.3 \\
\hline $\mathrm{SE}^{1}$ & & 0.21 & 0.10 & 32.4 & 4.2 \\
\hline
\end{tabular}

${ }^{1}$ Standard error.

\section{Discussion}

The reports about the addition of animal derived protein to the diet have documented inconsistent results in laying hens. Bozkurt et al. (2004) reported that meat and bone meal supplemented to diet slightly improved the production performance in laying hens at old age. Likewise, researcher suggested that egg production were not significantly affected by feeding based on feather meal or poultry by product meal (Senkoylu et al., 2005). Giuliotti and Cucco (1994), Oruseibio (1995) and Damron et al. (2001) noted that the inclusion of meat and bone meal up to a level of $6.0 \%$ had no negative effect on laying hen performance. The reason of the inconsistent result may be due the different process methods. However, Çatll et al. (2012) suggested that the laying diet supplemented with meat and bone meal had adverse effect on production performance. In current study we observed that the HRM, SSM, and CHM supplementation at $2.0 \%$ increased the hen-day production rate compared with BD treatment. Meanwhile, the average daily feed intake of laying hens in SSM treatment significantly increased compared with $\mathrm{BD}$ treatment. This may be explained the improved production performance.

On the other hand, it is well known that plant proteins are generally nutritionally imbalanced. Unless supplemented with animal proteins or free amino acids, plant-based diets may not meet the requirements of certain critical amino acids and vitamin $\mathrm{B}_{12}$ for the production of eggs and meat (Ravindran \& Blair, 1993). Bones contain high collagen content approximately 83\% (Eastoe \& Long, 1960), similar to bones the skin also contain a large amount of collagen (Zhao et al., 2009). Collagen and gelatin (refined collagen) are rich in hydroxyproline, proline, and glycine (Boomgaardt \& Baker, 1972; Berdanier, 1998), but deficient in most essential amino acids, such as tryptophan, sulfuraminoacids, and isoleucine. Thus, the supplementation of skin derived protein meal might balance the amino acid profile and therefore improved the production performance. However, the amino acid in SSM is higher than that in HRM and CHM according to our analysis data. This may be another explanation for the best production performance in SSM treatment among treatments.

Egg specific gravity is an indirect indicator of the amount of shell present in relation to the size of the egg (Roberts, 2004). In current study, the egg specific gravity was higher in SSM and CHM treatments. Here, we 
compared our results regarding the egg shell parameters with animal by-products such as meat and bone meal as well as feather meal due to limited information. Bozkurt et al. (2004) reported that the specific gravity of the eggs from hens receiving diets containing 2.0 or $4.0 \%$ meat and bone meal was higher than that of control hens. However, the eggshell strength and thickness, which are direct indicators of egg quality, were not affected by the increased egg gravity. The amount and thickness of egg shell have been found to be related to egg shell strength. However, the strength of an egg is determined not just by the amount of shell that is present, but also by the quality of construction of the shell (Roberts, 2004). Interestingly, the egg weight was decreased in skin derived protein supplemented treatments as the feeding time increased. Report suggested that the increased egg production rate of the hens receiving the meat and bone meal supplemented diets could have had a depressive effect on egg weight (Bozkurt et al., 2004). Furthermore, Straková et al. (2007) suggested that plant-based positively affect the egg weight. Thus, the supplementation of animal derived protein has adverse effect on egg weight.

The egg quality (egg yolk height, color, and Haugh Unit) was unaffected by dietary treatments. It is well accepted that the egg yolk color is correlated with pigment content, while yolk height and Haugh Unit are related to the viscosity of the thick albumen (Robert, 2004). Bozkurt et al. (2004) and Damron et al. (2004) reported that the $\mathrm{HU}$ value of the eggs from the hens fed the diet containing $6.0 \%$ meat and bone meal was significantly better than that of other dietary treatments. Senkoylu et al. (2005) also reported that feeding based on feather meal or poultry by product meal significantly affected internal egg qualities such as HU and albumen and yolk percentages. However, considering the difference of protein sources and variety of factors affect Haugh Unit. We believed that the skin derived protein have no detrimental effects to the egg internal quality.

The hen's state of health can be assessed objectively on the basis of regular haematological and biochemical tests (Straková et al., 2001; Straková et al., 2007). The result of haematological tests showed that the skin derived diets had no negative effect on haematological indicators. This statement is supported by the fact that the RBC, WBC, and lymphocyte indices in the experimental treatments did not differ from the BD treatment. Dietary treatments did not affect the serum total protein. The total serum protein consisted of albumin and globulin. Grandhi et al. (1975) reported that serum protein profiles varied with breed, strain, and age. Some researches (Eggum, 1989; Tewe, 1985; Bunchasak et al., 2005) suggested that total serum protein was directly responsive to both protein quantity and quality. However, Agbede and Aletor (2003) reported that total serum protein was not affect by sources of dietary protein. Our study was in agreement with the later report that skin derived protein did not influence the total serum protein. In addition, Chao and Lee (2001) have examined the association between the level of serum gamma-globulin and reproductive performance in Taiwan country chickens. They found that the high serum gamma-globulin level is genetically associated with low fertility. Unfortunately, we failed to examine the serum protein fractions which might be another evidence for the high production performance in SSM treatment.

\section{Conclusion}

In surmise, SSM in laying hen diet at $2 \%$ benefit the egg production without any detrimental effects on eggshell quality, egg internal quality and health status of laying hens. It indicated that SSM has potential to supply the bio- available amino acids and quality protein to the layer diet.

\section{References}

Agbede, J. O., \& Aletor, V. A. (2003). Evaluation of fishmeal replaced with leaf protein concentrate from gyricidia in diets for broiler chicks: Effect on performance, muscle growth, haematology and serum metabolites. International Journal of Poultry Science, 4, 242-250.

AOAC. (2003). Official Methods of Analysis (17th ed.), Association of Official Analytical Chemists. Arlington, V. A.

Berdanier, C. D. (1998). Advanced nutrition: Micronutrients. CRC Press, Boca Raton, FL.

Boomgaardt, J., \& Baker, D. H. (1972). Sequence of limiting amino acids in gelatin for the growing chick. Poulty Science, 51, 1650-1655. http://dx.doi.org/10.3382/ps.0511650

Bozkurt, M., Alçiçek, A., \& Çabuk, M. (2004). The effect of dietary inclusion of meat and bone meal on the performance of laying hens at old age. South African Journal of Animal Science, 34, 31-36. http://dx.doi.org/10.4314/sajas.v34i1.3807

Bunchasak, C., Poosuwan, K., Nukraew, R., Markvichitr, K., \& Choothesa, A. (2005). Effect of dietary protein on egg production and immunity response of laying hens during peak production period. International Journal of Poulty Science, 4, 701-708. http://dx.doi.org/10.3923/ijps.2005.701.708 
Çatlı, A. U., Bozkurt, M., Küçükyılmaz, K., Çınar, M., Bintaş, E., Çöven, F., \& Atik, H. (2012). Performance and egg quality of aged laying hens fed diets supplemented with meat and bone meal or oyster shell meal. South African Journal of Animal Science, 42, 74-82.

Chao, C. H., \& Lee, Y. P. (2001). Relationship between reproductive performance and immunity in Taiwan country chickens. Poultry Science, 80, 535-540. http://dx.doi.org/10.1093/ps/80.5.535

Dale, N. (1997). Metabolizable energy of meat and bone meal. Journal of Applied Poultry Research, 6, $169-173$. http://dx.doi.org/10.1093/japr/6.2.169

Damron, B. L., Ouart, M. D., \& Christmas, R. B. (2001). Rendered whole-bird layer mortality as an ingredient in layerdiets. Journal of Applied Poultry Research, 10, 371-375. http://dx.doi.org/10.1093/japr/10.4.371

Duncan, D. B. (1955). Multiple range and multiple F tests. Biometrics, 11, 1-42. http://dx.doi.org/10.2307/3001478

Eastoe, J. E., \& Long, J. E. (1960). The amino-acid composition of processed bones and meat. Journal of the Science Food and Agriculture, 11, 87-92. http://dx.doi.org/10.1002/jsfa.2740110204

Eggum, B. O. (1989). Biochemical and methodological principles. In H. D. Bock, B. Eggum, A. G. Low, O. Simon, \& T. Zebrowska (Eds.), Protein metabolism in farm animals. Evaluation, Digestion, Absorptionand Metabolism (pp. 1-52). Oxford Science Publication, Deutscher Handwirtschafts Verlag, Berlin.

European Commission. (2005). The TSE Roadmap. Retrieved May 5, 2012, from http://ec.europa.eu/geninfo/query/resultaction.jsp? Page $=2$

Giuliotti, L., \& Cucco, E. (1994). Administration of vegeTable diets or diets with animal proteins and fats tolaying hens. 1. Productive Traits. Rivista-di-Avicoltura, 63, 29-32.

Grandhi, R. R., Brown, R. G., Reinhart, B. S., \& Summers, J. D. (1975). Thyroid metabolism in the recessive sex-linked dwarf female chicken. 2. Binding of thyroid hormones by serum proteins. Poultry Science, 54, 493-499. http://dx.doi.org/10.3382/ps.0540503

Karakas, P., Versteegh, H. A. J., van der Honing, Y., Kogut, J., \& Jongbloed, A. W. (2001). Nutritive value of the meat and bone meals from cattle or pigs in broiler diets. Poultry Science, 80, 1180-1189. http://dx.doi.org/10.1093/ps/80.8.1180

Leeson, S., \& Zubair, A. K. (1994). Digestion in poultry: protein and fats. Animal Poultry. University of Guelph. Canada, NIG 2 WI.

Lindemann, M. D., Cromwell, G. L., Monegue, H. J., Cook, H., Soltwedel, K. T., Thomas, S., \& Easter, R. A. (2000). Feeding value of an enzymatically digested protein for early-weaned pigs. Journal of Animal Science, 78, 318-327.

McDonald, P., Edwards, R. A., Greenhalgh, J. F. D., \& Morgan, C. A. (2002). Animal Nutrition. Pearson Education limited, Edinburgh Gate, Harlow, Essex.

NRC. (1994). Nutrient Requirements of Poultry (9th rev. ed.). National Academy Press, Washington, DC.

Oruseibio, S. M. (1995). Comparison of straight protein diets with mixed protein diets on egg production. Discovery and Innovation, 7, 151-162.

Parsons, C. M., Castanon, F., \& Han, Y. (1997). Protein and amino acid quality of meat and bone meal. Poultry Science, 76, 361-368. http://dx.doi.org/10.1093/ps/76.2.361

Pinheiro, J. W., Mizubuti, Y. I., Rocha, M. A., \& Reddy, K. V. (1989). Utilization of leather meal in broilers. Semina: Ciências Agrárias, 10, 41-45.

Ravindran, V., \& Blair, R. (1993). Feed resources for poultry production in Asia and Pacific. 3. Animal Protein Sources. Worlds Poultry Science Journal, 49, 219-235. http://dx.doi.org/10.1079/WPS19930020

Roberts, J. R. (2004). Factors affecting egg internal quality and egg shell quality in laying hens. Journal of Poultry Science, 41, 161-177. http://dx.doi.org/10.2141/jpsa.41.161

Sahraei, M., Janmohammadi, H., Lashkari, S., Torkamani, M. D., \& Gituee, A. (2012). Evaluation of protein quality in hydrolyzed protein meals by biological assay methods in broiler chickens. International Journal of Agriculture: Research and Review, 2, 352-356.

SAS. (1996). SAS user's guide. Release 6.12 Editions. SAS Institute. Inc Cary NC. USA. 
Sell, J. L., \& Jeffrey, M. J. (1996). Availability for poultry of phosphorus from meat and bone meals of different particle sizes. Poulty Science, 75, 232-239. http://dx.doi.org/10.3382/ps.0750232

Senkoylu, N., Samli, H. E., Akyurek, H., Agma, A., \& Yasar , S. (2005). Performance and egg characteristics of laying hens fed diets incorporated with poultry by-product and feather meals. Poultry Science Association, 542, 1-6.

Simeonova, L. S., \& Dalev, P. G. (1996).Utilization of a leather industry waste. Waste management, 16, 765-769.

Straková, E, Večerek, V.,Suchý, P., \& Křesala, P. (2001). Red and white blood-cell analysis in hens during the laying period. Czech Journal of Animal Science, 46, 388-392. http://dx.doi.org/10.2754/avb200776S8S031

Straková, E., Suchý, P.,Šugerková, M., \& Macháček, M. (2007). Positive effect of plant-based diet on the performance and health of laying hens. Acta Veterinaria Brno, 76, S31-S37.

Tewe, O. O. (1985). Protein metabolism in growing pigs fed corn or cassava peel based diets containing graded protein levels. Research Veterinary Science, 29, 259-263.

vanKrimpen, M. N., Veldkamp, T., Binnendijk, G. P., \& de Veer, R. (2010). Effect of four processed animal proteins in the diet on digestibility and performance in laying hens. Poultry Science, 89, 2608-2616. http://dx.doi.org/10.3382/ps.2010-00696

Waldroup, P. (2002). The future of poultry nutrition. Poultry International, 41, 12-19.

Woodgate, S. L. (1994). The use of enzymes in designing a perfect protein source for all animals. In T. P. Lyons (Ed.), Biotechnology in the Feed Industry (pp. 67-81). Proceedings of Alltech's Tenth Annual Symposium.

Yan, L., Meng, Q. W., Ao, X., Wang, J. P., Jang, H. D., \& Kim, I. H. (2011). Evaluation of dietary wild-ginseng adventitious root meal on egg production, egg quality, hematological profiles and egg yolk fatty acid composition in laying hens. Livestock Science, 140, 201-205. http://dx.doi.org/10.1016/j.livsci.2011.03.033

Zhao, S., Zhang, M., Li, G. Y., \& Liu, W. T. (2009). Preparation and characterization of alkali-soluble collagen from pigskin shavings. The Journal of the American Leather Chemists Association, 104, 344-351.

\section{Copyrights}

Copyright for this article is retained by the author(s), with first publication rights granted to the journal.

This is an open-access article distributed under the terms and conditions of the Creative Commons Attribution license (http://creativecommons.org/licenses/by/3.0/). 